\title{
Where now for stem-cell cloners?
}

Scientists are surveying the wreckage left by the debacle involving stem-cell researcher Woo Suk Hwang after three co-authors on his landmark paper said that it could not be trusted. Researchers now face a long slog to rebuild the foundations of their field.

As well as issues relating to trust and public confidence in such a controversial area (see page 1056), the complete loss of confidence in Hwang's work has set the field back by years. It has also taken away what seemed to be firm confirmation of the feasibility of using cloning to produce patient-matched stem cells.

"We thought a fundamental question had been answered," says Alison Murdoch of the University of Newcastle Upon Tyne, UK. ${ }^{\alpha}$ Hwang's results shifted the research focus on to emulating his work. Now we may need to look again at that fundamental step."

Hwang's group daimed two major papers in the past two years that revolutionized the field. In 2004, the group reported that it had doned a cell obtained from an adult woman (W. S. Hwang et al. Science 303, 1669-1674; 2004). The group claimed it had put DNA from the woman's cell into one of her own eggs, from which the genetic material had been removed. After several days, the egg had developed into a distinct type of early embryo called a blastocyst. From this, Hwang's group supposedly extracted a batch of embryonic stem cells, potentially capable of developing into any of the body's tissues.

Earlier this year, the group reported that it had vastly improved on this study (W. S. Hwang et al. Science 308, 1777-1783; 2005). The researchers used the same procedure but this time claimed to have transferred genetic material from patients into eggs from unrelated, healthy women, to create blastocysts and extract stem cells. The increased efficiency they claimed also meant that far fewer eggs were needed to create stem-cell lines.

The paper was hailed as a milestone. It apparently provided the first proof of stem cells matched to individual patients and suggested that they were not that difficult to make, confirming the promise of the technique - dubbed "therapeutic cloning" - for producing replacement cells and tissues. It also seemed to settle lingering questions about whether cloning actually worked. Many scientists had not been convinced by the results of Hwang's 2004 experiments. Because the egg and donor DNA came from the same person, it was impossible to be sure that the stem-cell line was created from the donor cell instead of the egg.

In the past few days, doubts have also been raised about the authenticity of the 2004 paper (see page 1056). But whether it is valid or not, the loss of confidence in the 2005 study leaves scientists with no proof that adult cells can be cloned - let alone used to produce stem cells. "Hwang's work gave people confidence to move into this difficult area," says Alan Colman, head of Singapore-based regenerativemedicine company ES Cell International and a member of the team that cloned Dolly. "But maybe it's harder than we thought."

"We're back to knowing that animal cloning is possible but wondering whether it is possible in humans," adds Kevin Eggan of Harvard University in Cambridge, Massachusetts. "This is an enormous setback."

With Hwang's work set aside, results from other groups are sparse. After Hwang's apparent success, researchers flocked to his lab to learn his methods, but most, such as Eggan, and George Daley of Harvard Medical School, are still waiting to get approval to use them in their home countries.

There have been a few baby steps, however. In 2001, a company called Advanced Cell Technology (ACT), based in Worcester, Massachusetts, described its attempt to create cloned human blastocysts. But the group's clones survived only a few days and never made it to the blastocyst stage (J. B. Cibelli et al. J. Regen. Med. $2,25-31 ; 2001)$. The researchers abandoned their work because of lack of funding once Hwang claimed success.

In 2002, Chinese researchers made headlines with a report that Guangxiu Lu of the Xiangya

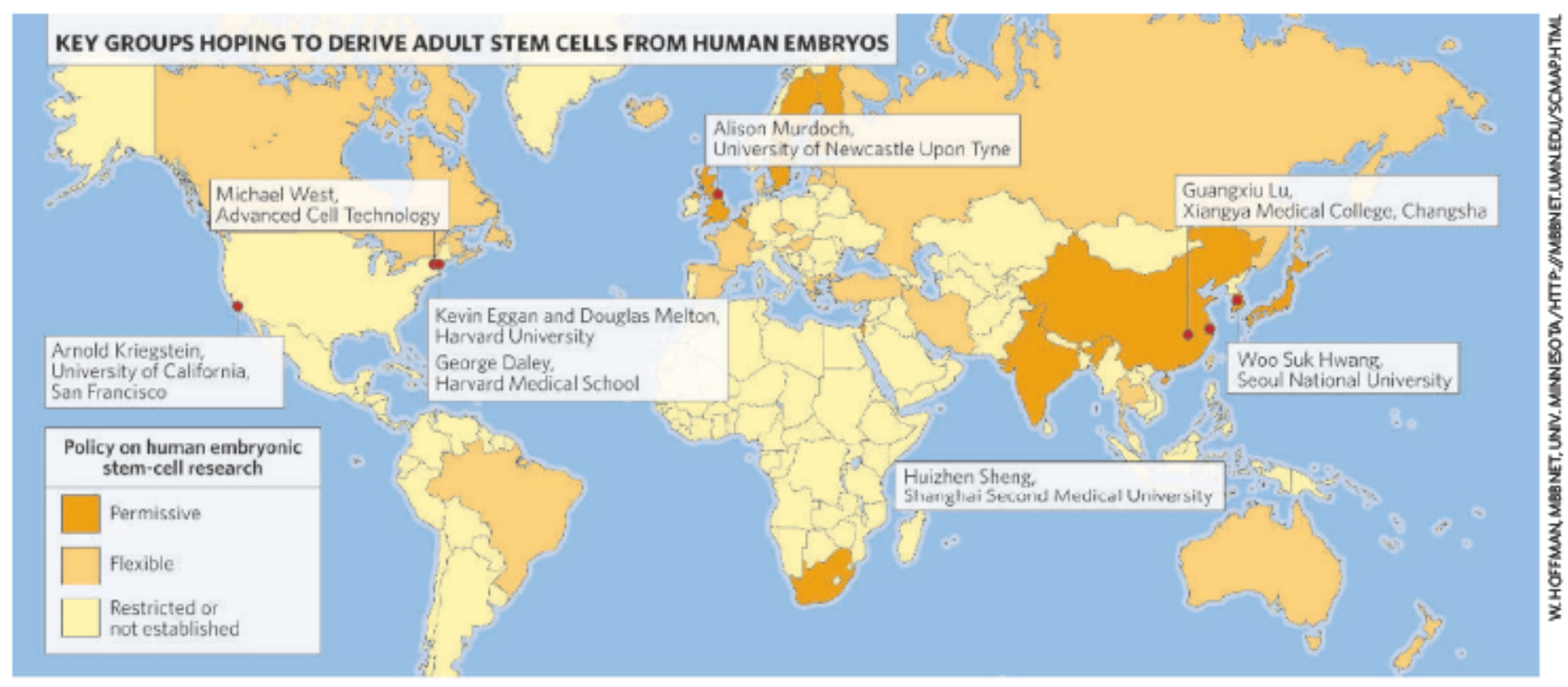




\section{Dogged by doubts}

Is Snuppy really a clone? With the credibility of his creator Woo Suk Hwang under fire, the dog's credentials are being challenged. The Afghan hound was supposedly the first dog to be cloned (B.C. Leeet al Nature 436, 641; 2005). Cloning dogs presents unusual challenges because, compared with other mammals, the egg cells are difficult to mature in vitro. Hwang's group says it used the same technology as in its human experiments removing the nucleus from a donor's cell and inserting itinto an egg cell, a process called somatic-cell nuclear transfer (SCNT).

But Robert Lanza, a stem-cellexpert at Advanced Cell Technology in Worcester, Massachusetts, and a competitor with Hwang in human therapeutic cloning, says the paper should now be seriously re-examined.

Lanza says that Snuppy, seen on the right with the dog from which he was supposedly cloned, mighthave been created by a technique called embryo splitting, in which cells from an early-stage embryo are divided and then implanted separately. The technique creates identical twins. One set of cells could have been used immediately to create a dog while another was frozen and stored. If the frozen cells were later used to create a dog with identical DNA, that could be presented as an SCNT clone.

Medical College in Changsha, Hunan, had cloned human blastocysts from adult cells (Chinese Sci. Bull. 48, 1840-1843; 2003), although she had not been able to extract stem cells from any of them. Also, Huizhen Sheng of Shanghai Second Medical University claimed to have extracted stem cells from embryos created by introducing adult human DNA into rabbit eggs stripped of their own chromosomes (Y. Chen et al. Cell Res. 13,251-263;2003).

And in August, Murdoch's group reported the creation of a single blastocyst from a cloned cell (M. Stojkovic et al. Reprod. BioMed. Online $11,226-231 ; 2005)$. The blastocyst died before yielding any stem cells. And as the cloned cell was itself an embryonic stem cell, the paper does not show a way of making stem cells matched to adult patients from scratch.

Murdoch says she does not relish now being a leader in the field. "I'm not interested in striving to be the first to get somewhere," she says. "The problems in South Korea highlight the difficulties in racing to get results."

She also laments the rules and regulations that many scientists think have hamstrung stem-cell research (see map, opposite). ${ }^{\alpha}$ The more people who are working on this the better," she says. "But the fundamental problem

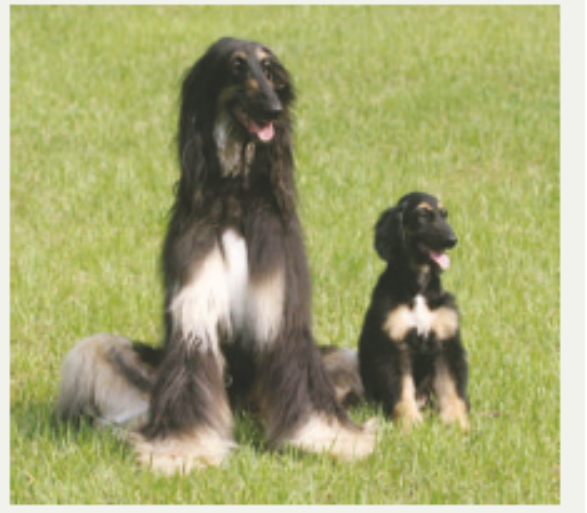

Such trickery could becaught by examining mitochondrial DNA, which is passed maternally with the egg cell. If Snuppy were really a SCNT clone, he should have the mitochondrial DNA of the dog from which the egg was taken. If he's a fake, he'd share it with the dog from which he was supposedly cloned.

Mitochondrial DNA data have notbeen part of previous cloning papers, and were not presented in Nature, Lanza suggests that it would now be a good idea to do the test. "If the mitochondrial DNA is the same, that's the end of that paper," says Lanza.

Nature is starting an investigation, including a mitochondrial DNA test, that is unlikely to be complete before January 2006.

David Cyranoski

is that it is banned in so many countries."

But researchers in the field are hopeful that progress can be made. ${ }^{\alpha}$ This needs to be done right," says Michael West of ACT. "And many of us are determined to make it happen." He says his company now plans to revisit the work. Eggan and Douglas Melton, also at Harvard University, hope to get approval from the review boards that oversee their research in time to start work cloning human embryos early next year. Daley is planning experiments similar to those done by Murdoch's group. And Arnold Kriegstein and his group at the University of California, San Francisco, plan to try to replicate Hwang's methods with their own materials.

But for others, the episode merely confirms that therapeutic cloning is not the way forward. "I always had my doubts about therapeutic cloning to generate patient-matched cells," says Stephen Minger, a stem-cell researcher at the Wolfson Centre for Age Related Diseases in London, UK. He believes that banking stemcell lines from normal embryos, so that they can be matched to patients once they are made, is a more realistic prospect.

Erika Check

Additional reporting by Tom Simonite and

Carina Dennis 